\title{
Feeding of the planktonic shrimp Lucifer faxoni Borradaile, 1915 (Crustacea: Decapoda) in the laboratory
}

\author{
Luz Amelia VEGA-PÉREZ; Koichi ARA; Tsui Hua LIANG \& Marcelo Mattos PEDREIRA
}

Instituto Oceanográfico da Universidade de São Paulo

(Caixa Postal 66149, 05389-970 São Paulo,SP, Brasil)

- Abstract: Fceding behavior of juveniles of the planktonic shrimp Lucifer faxoni Borradaile was studied in the laboratory under light and dark conditions. Newly-hatched nauplii and metanauplii of Artemia were used as prey organisms. The fecding rate of $L$. faxon $i$ was dependent on prey size and prey density, but was not obviously affected by light or dark conditions. The capture of the prey tended to increase with longer exposure time to prey. The maximum ingestion rate was 17.28 and 13.40 nauplii.L: faxoni ${ }^{-1} \cdot \mathrm{d}^{-1}$, in the light and in the dark conditions, respectively.

- Resumo: O comportamento alimentar de espécimens jovens de Lucifer faxoni Borradaile, em laboratório, sob condições de luz. e escuro, foi estudado utilizando-se como alimento náuplios recém-eclodidos e metanáuplios de Artemia. Neste estudo a taxa de alimentação de $L$. faxoni foi influenciada pelo tamanho e concentração da presa, bem como pelo tempo de contato com a mesma. A atividade alimentar de $L$. faxoni foi maior em condições de luz, quando comparado com as condições de escuro. A taxa máxima de ingestão calculada foi de 17,28 e 13,40 náuplios. $L$. faxoni ${ }^{-1} . \mathrm{d}^{-1}$ para as condiçôes de luz e escuro, respectivamente.

- Descriptors: Feeding behavior, Predation rate, Marine carnivory, Lucifer faxoni, Zooplankton.

- Descritores: Comportamento alimentar, Taxa de predação, Carnivoria, Lucifer faxoni, Zooplâncton marinho.

\section{Introduction}

The feeding mechanisms are worth studying in order to answer basic questions about how evolution has shaped feeding behavior and how this behavior will affect community structure and function (Båmstedt, 1988).

Carnivorous feeding of zooplankton may play an important role in the regulation of prey populations (Hopkins et al., 1993), and consequently in determining community structure. Feeding behavior and energetics of carnivorous feeding of zooplankton species have been studied (Lampitt \& Gamble, 1982; Yen, 1983; Recve et al., 1989; Oresland \& Ward, 1993).

The planktonic shrimp Lucifer faxoni Borradaile is regarded as an important component of the carnivorous

Contr. no. 793 do Inst. oceanogr. da Usp. zooplankton in tropical and subtropical neritic waters in the Atlantic. It is abundant and widely distributed in the neritic waters along the eastern coasts of North America (Hopkins, 1966; Bowman \& McCain, 1967; Omori, 1977) and South America (López, 1966; Harper, 1968; Jimenez-Alvarez, 1976). In Brazilian coast it is distributed from Pará State to Lagoa dos Patos (Barth, 1963). This species have been found abundantly in Ubatuba, São Sebastião and Cananéia regions (São Paulo State). In these localities, its role in trophodynamic pathways must be important (Vega-Pérez, 1993; 1996), since it constitutes one of the most important food items found in the stomach contents of fishes (Gasalla, 1995; Wakabara et al., 1996).

In general, studies on this species have been concerned mainly with other aspects of its ecology than feeding behavior (Woodmansee, 1966a,b; Harper, 1968; Omori, 1977). Information related to its fecding behavior is limited to Lee et al. (1992). 
This study was conducted to contribute to our understanding of the feeding behavior of $L$. faxoni under laboratory conditions. The goal is to determine predation rate at different food concentrations using two sizes of prey under different light condition.

\section{Material and methods}

Zooplankton samples and seawater were collected on September 20-23, 1994 off Ubatuba region, São Paulo State, Brazil (Fig. 1). Oblique hauls were made using a $505 \mu \mathrm{m}$ mesh ring net of $1 \mathrm{~m}$ diameter, which was towed between the surface and $12 \mathrm{~m}$ depth for $5 \mathrm{~min}$ at ship velocity of ca. 1.0 - 1.5 knots. Samples were transfered into plastic containers and transported immediately to the laboratory.

Juvenile females specimens of $L$. faroni (mean of total length $=3.84 \pm 0.99 \mathrm{~mm}$; mean wet-weight $=239.19 \pm$
$111.90 \mu \mathrm{g}$ ) were sorted with pipette and placed individually in small glass bowls (diameter $9 \mathrm{~cm}$ and depth $7 \mathrm{~cm}$ ), containing approximately $100 \mathrm{ml}$ filtered seawater with salinity 34.00. All specimens were maintained at room temperature of $21.5-27.0^{\circ} \mathrm{C}$ in starved condition for $6 \mathrm{~h}$ before the experiments begun.

Three aspects of feeding behavior of $L$. faxoni were studied: (1) influence of prey concentration; (2) effect of prey size; (3) influence of light and dark conditions.

In the feeding experiments newly-hatched Artemia nauplii (mean length $=0.46 \pm 0.036 \mathrm{~mm}$; mean wet-weight $=14 \mu \mathrm{g}$ ) and metanauplii (mean length $=0.62 \pm 0.042$ $\mathrm{mm}$; mean wet-weight $=17.3 \mu \mathrm{g}$ ) were used as the prey at four different concentrations: 10, 20, 40 and 80 individuals per bowl. These experiments were conducted for $6 \mathrm{~h}$ under light and dark conditions.

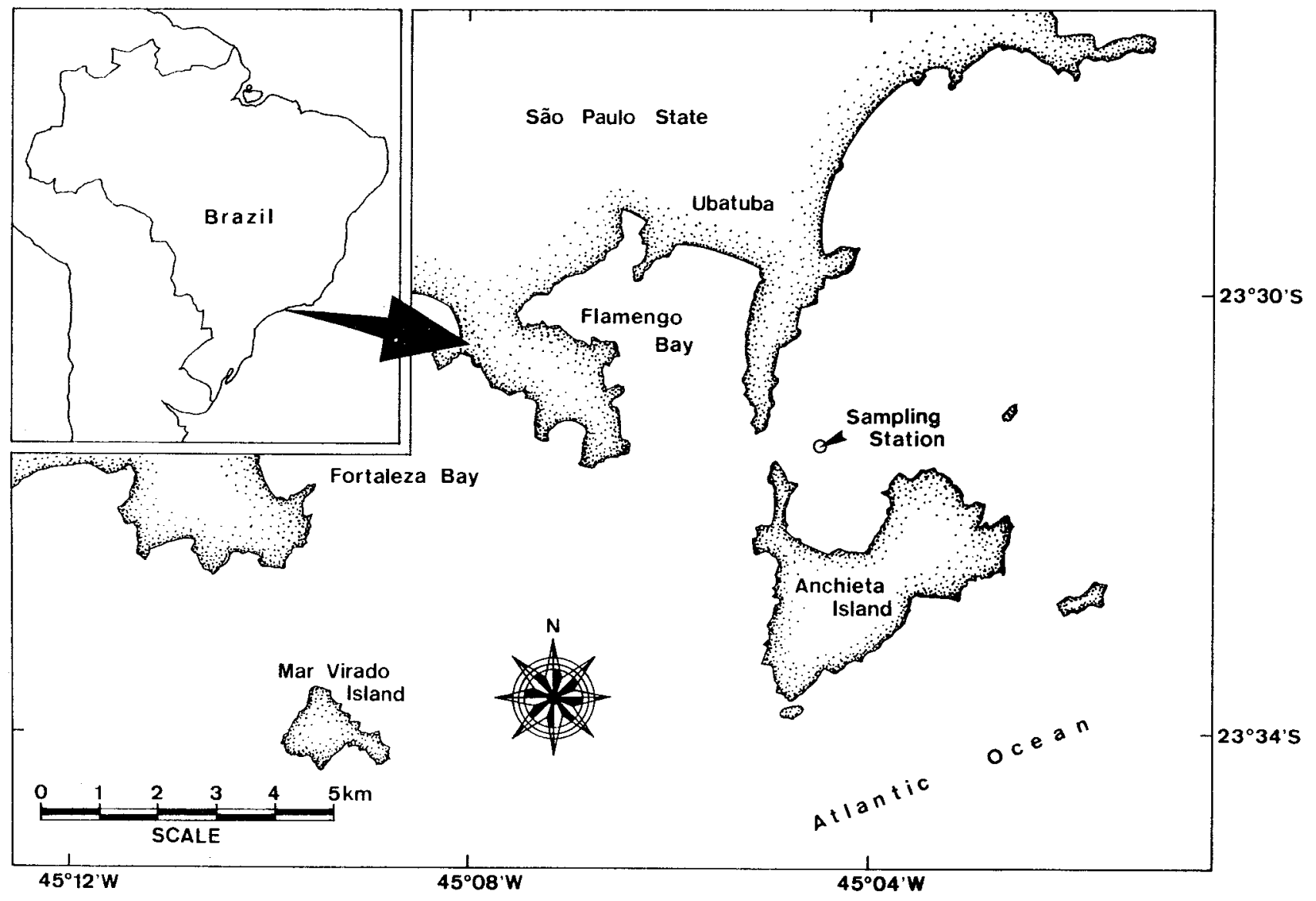

Fig. 1. Map showing the location of the sampling station in Ubatuba region, São Paulo-Brazil. 
Additional experiments were made to determine the effect of longer exposure time ( $9 \mathrm{~h}$ and $12 \mathrm{~h}$ ) of $L$. faxoni fed with 20 newly-hatched nauplii prey. During the experiment no molt of $L$. faxoni was observed.

At the end of each experiment, specimens of $L$. faxoni were carefully removed from the bowl, and the number of prey remaining in each bowl were counted. When the prey was partially consumed, i.e. about half of body, it was registered as 0.5 individual. $L$. faxoni specimens were frozen after the experiments to avoid alterations in the length and weight, since the meansurements were processed in the period of $48 \mathrm{~h}$.

The relationship between the length of pre-bucal somite and total length of $L$. faxoni was observed by Lópes (1966). Pre-bucal somite was measured, from the tip to the posterior edge, under a stereomicroscope Wild M5 using a micrometer scale. Measurements of wet-weight were made with electronic microbalance (Sauter Co. Ltd., Model D81) by placing a known number of individuals on a alumnium foil.

From length and weight data of $L$. faxoni, the following regression equation was obtained:

$$
W=308.653 L^{2.489}(r=0.883),
$$

where $\mathrm{W}$ and $\mathrm{L}$ are the weight $(\mu \mathrm{g})$ and length $(\mathrm{mm})$, respectively. This equation was used to calculate the weight of a single $L$. faxoni.

Ivlev's equation modified by Parsons et al. (1969) was fitted to the mean values of ingestion rates obtained from the experiments to express the functional response of the
L. faxoni in terms of nauplii.L. faxoni $i^{-1} \cdot \mathrm{d}^{-1}$, and $\mu \mathrm{g}$ nauplii.L. faxoni ${ }^{-1} \cdot \mathrm{d}^{-1}$ :

$$
I=I_{\max }\left(1-e^{-d(p o-p)}\right),
$$

where $I$ is the ingestion rate; $I_{\max }$ is the theoretical maximum rate of ingestion; $d$ is the constant; $p$ is the prey density, and po is the threshold prey density below which no feeding takes place.

For all statistical comparisons, one-way analysis of variance (ANOVA) and Tukey multiple comparison test were applicd (Sokal \& Rohlf, 1981).

\section{Results}

In laboratory conditions, $L$. faxoni generally ate their prey whole, although sometimes partial consumption has been observed.

Throughout the series of experiments, a large number of L. faxoni ( $82.09 \%$ ) was observed preying on newly-hatched Artemia nauplii and metanauplii, whereas $17.91 \%$ of the $L$. faxoni had not ingested prey.

The mean values of individual ingestion rates varied with the prey size, prey density and light/dark conditions (Table 1). The number of prey ingested in the $6 \mathrm{~h}$ experiments was variable. Nearly $70.92 \%$ of $L$. faxoni consumed 1-5 prey items, $9.91 \%$ captured 6-11 prey and only $0.70 \%$ ingested 13 nauplii (Fig. 2). Higher percentage of capture was verified in light conditions (Fig. 3).

Table 1. Means ( \pm SE) of ingestion rates (express per day) of L. faxoni preying upon Artemia

\begin{tabular}{|c|c|c|c|c|c|c|}
\hline PREY DENSITY & $\mathbf{N}$ & \multicolumn{2}{|l|}{ LIGHT } & $N$ & \multicolumn{2}{|l|}{ DARK } \\
\hline \multicolumn{7}{|c|}{ Newly hatched naupli i } \\
\hline 10 & 8 & 1.5 & $(0.420)$ & 9 & 1.11 & $(0.587)$ \\
\hline 20 & 10 & 3.15 & $(0.487)$ & 9 & 1.87 & $(0.407)$ \\
\hline 40 & 10 & 2.55 & $(0.449)$ & 10 & 2.9 & $(0.737)$ \\
\hline 80 & 10 & 3 & $(0.882)$ & 9 & 2.39 & $(0.623)$ \\
\hline \multicolumn{7}{|l|}{ Metanaupli i } \\
\hline 10 & 5 & 1.9 & $(0.675)$ & 5 & 3.8 & $(0.581)$ \\
\hline 20 & 10 & 3.5 & $(0.819)$ & 10 & 1.6 & $(0.452)$ \\
\hline 40 & 7 & 5.42 & $(1.822)$ & 9 & 2.89 & $(0.827)$ \\
\hline 80 & 10 & 4.5 & $(1.325)$ & 9 & 3.78 & $(0.923)$ \\
\hline
\end{tabular}
newly-hatched nauplii and metanauplii. 


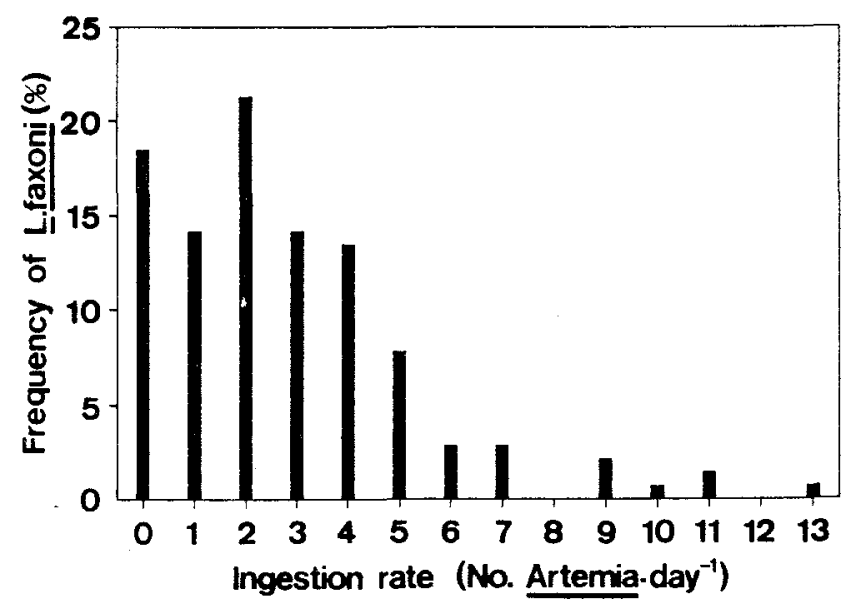

Fig. 2. Frequency (\%) and ingestion rate (No. Artemia. day ${ }^{-1}$ ) of L. faxoni.
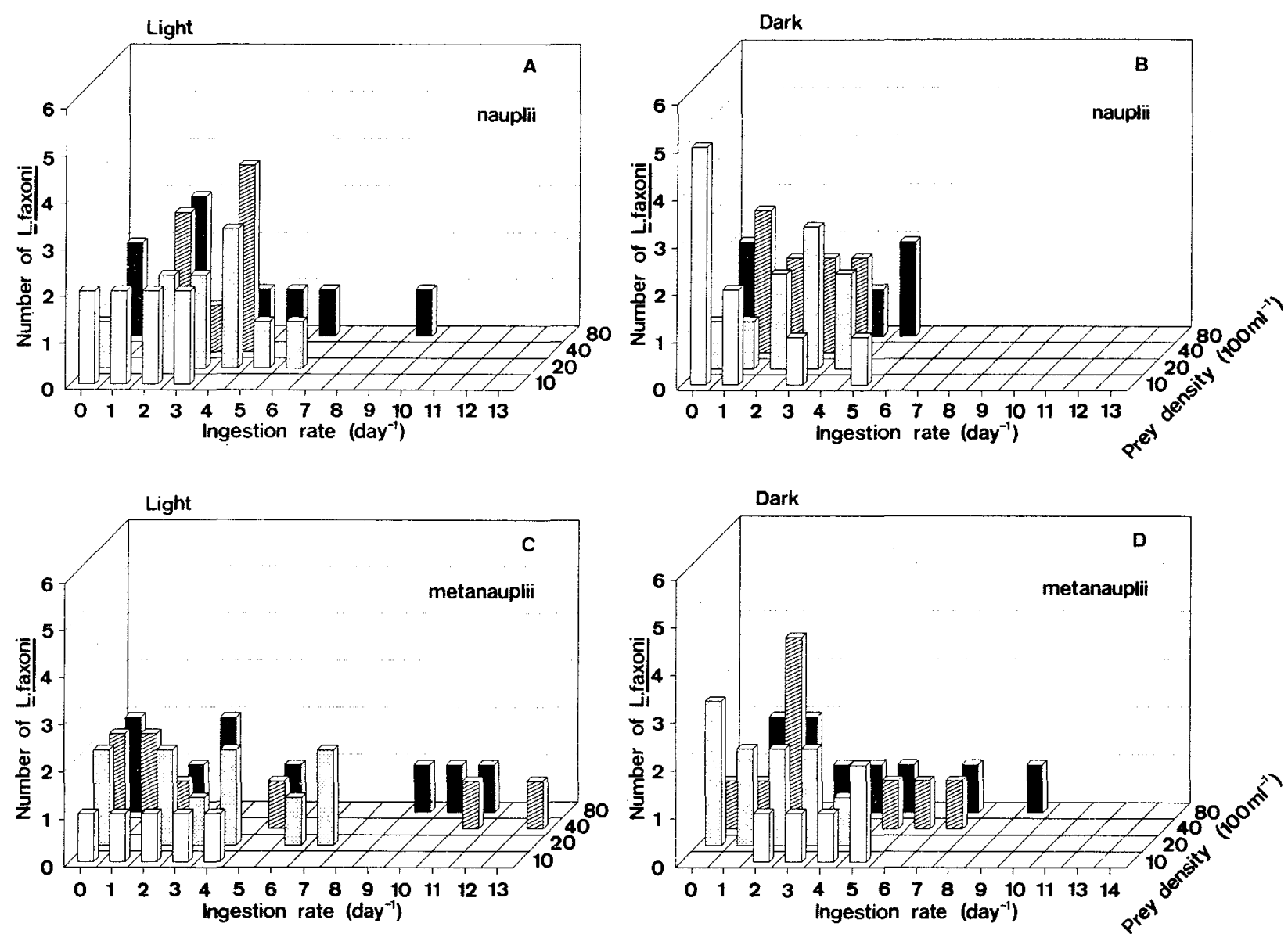

Fig. 3. Ingestion rate (express per day) of $L$. faxoni preying upon Artemia nauplii (A, B) and metanauplii $(C, D)$, in light and dark conditions. 

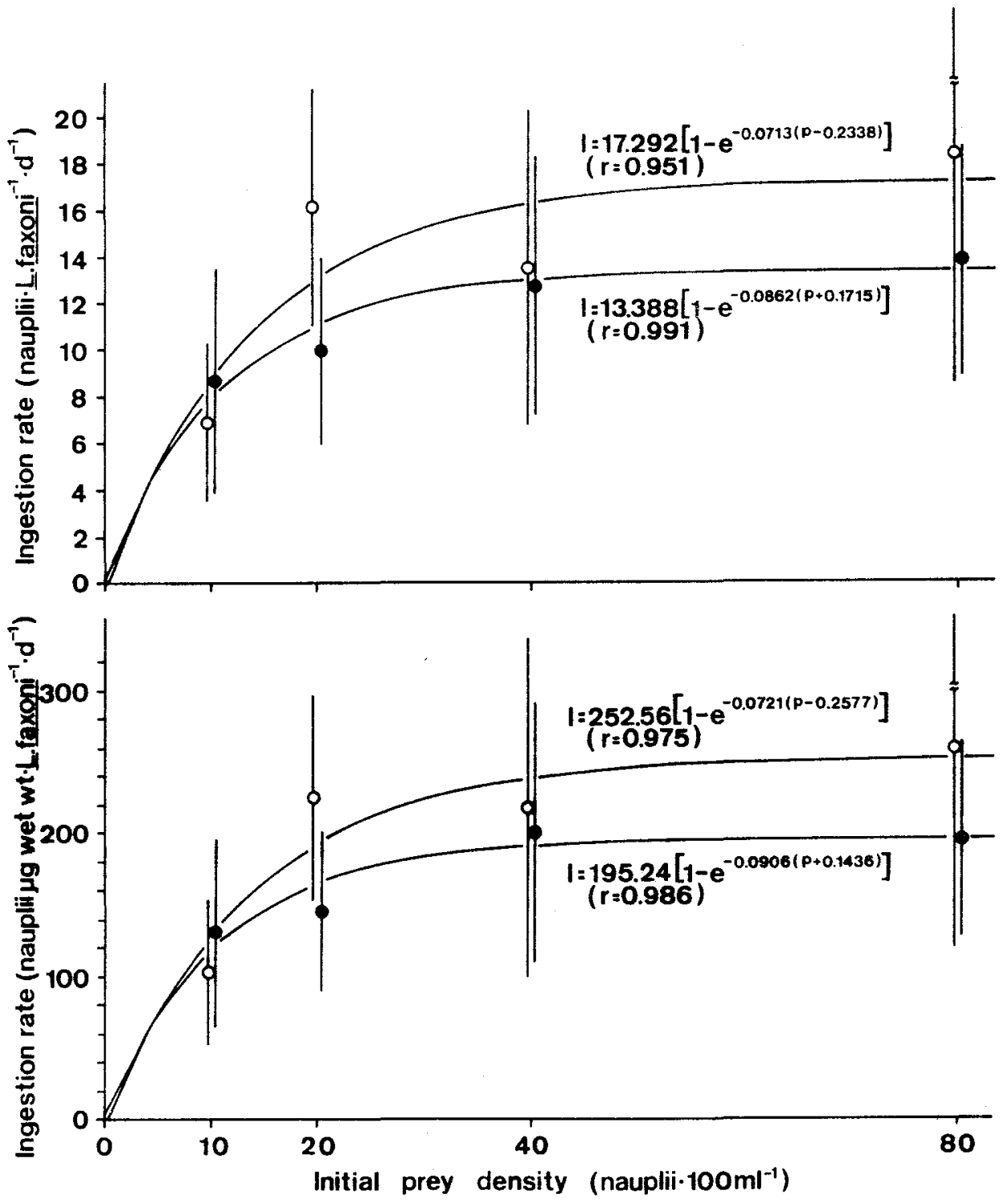

Fig. 4. Ingestion rate of $L$ faxoni on different prey density (Ivlev's function), in light(o) and dark $(\bullet)$ conditions.

The other experiments made to determine the effect of longer exposure time ( $9 \mathrm{~h}$ and $12 \mathrm{~h}$ ), utilizing 20 Artemia nauplii, showed that the capture tended to increase with longer exposure time to prey (Fig. 5). Tukey multiple comparison test showed the differences in the $6 \mathrm{~h}$ and $9 \mathrm{~h}$ experiments under light conditions were statistically significant. For the other trials, the differences were not statistically significant.

In all experiments the mean ingestion rate was higher in the light conditions, although they were not statistically significant $(\mathrm{p}<0.05)$.

\section{Discussion}

In laboratory conditions, $L$. faxoni generally ate their prey whole, but the partial consumption was also observed.
These feeding behavior has been reported in other crustaceans such as the prawn Crangon crangon (Gibson $e t$ al., 1995).

The number of prey ingested by $L$. faxoni in the laboratory was highly variable ranging from 0 to 13 Artemia nauplii. Nearly $17.9 \%$ did not feed. The reason for this large variation could be due to the physiological state of $L$. faxoni since feeding can vary due to stress of collection and acclimation period (Chow-Fraser, 1986).

Prey size is one of the several factors affecting prey encounter rate and the predator ability and willingness to capture and ingest prey (Oresland \& Ward, 1993). In this study, L. faxoni preyed more efficiently on Artemia metanauplii than on newly- hatched nauplii. The difficulty in capturing the nauplii may be due to the inability of this 


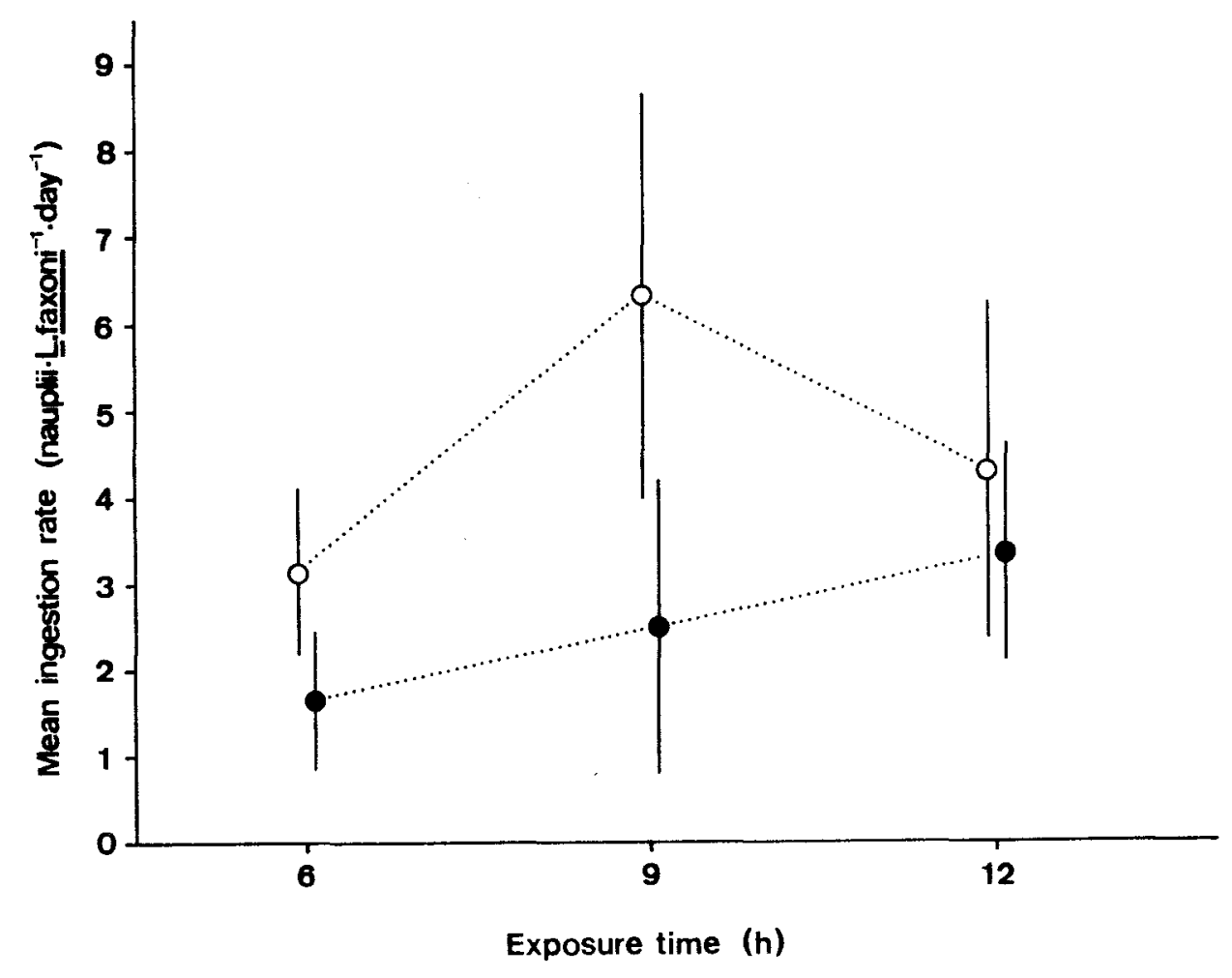

Fig. 5. Mean ingestion rate (express per day) of $L$. faxoni, with relation of exposure time to newly-hatched Artemia nauplii, in light(o) and $\operatorname{dark}(\bullet)$ conditions.

species to manipulate smaller prey, as reported for other prawns (Wassenberg \& Hill, 1993; Gibson, 1995). Another possible explanation for this result is that Artemia metanauplii are able to swim more actively than nauplii and then, they would be detectable at a greater range. This is probably because of the disturbances caused by the beating of the swimming appendages or by the prey's presence in the swimming current of the predator (Landry, 1978; Ohman, 1988).

Another factor which affects the ingestion rate is the abundance of food (Valiela, 1984). In this study, higher prey densities resulted in higher ingestion rate, but the relationship curve was asymtoptic. Lee et al. (1992) showed that the ingestion rate of adult females of $L$. faxoni increased with increasing food density, and it did not appear to saturate at higher food concentration (100 nauplii. $1^{-1}$ ) in the laboratory condition.

The ingestion rate was slightly higher in the light conditions than dark condition, it was not significantly different, however, between light and dark experiments, indicating that perceptions of prey may occur without visual cues. Besides visual perception, the detection of prey for the $L$. faxoni would be a chemo- or mechanoreception process. Although at present little is known about the relative importance of chemo- and mechanoreception in predator recognition.

In this study longer exposure time of predator to the prey tended to increase the number of Artemia captured by $L$. faxoni. These results confirm that food will be successfully captured when the feeder is exposed longer to the presence of its food (Andrews, 1983).

The information obtained in this study confirms that further field and laboratory studies on feeding rate of $L$. faxoni are required for better understanding the potential contribution of this species to the marine secondary production in the studied region.

\section{Acknowledgments}

We are grateful to Dr Jefferson T. Turner (University of Massachusetts - Dartmouth) and two anonymous reviewers for their critical comments on the manuscript. We would also thank Dr Y. Matsuura (Instituto Oceanográfico - USP) for his help in the analysis of nonlinear parameter estimation and M.Sc. N. Chung for the English review. This research was supported by Brazilian government through CNPq and CAPES. 


\section{References}

Andrews, J. C. 1983. Deformation of the active space in the low Reynolds number feeding current of calanoid copepods. Can. J. Fish. aquat. Sci., 40:1293-1302.

Båmstedt, U. 1988. Ecological significance of individual variability in copepod bioenergetics. Hydrobiologia, 167/168:43- 59.

Barth, P. 1963. Estudos sobre Lucifer reynaudi como indicador de águas tropicais. Notas Tecn. Inst. Pesq. Mar., Rio de Janeiro, 12:1-16.

Bowman, T. E. \& McCain, J. C. 1967. Distribution of the planktonic shrimp Lucifer in the western North Atlantic. Bull. mar. Sci., 17:660-671.

Chow-Fraser, P. 1986. Effect of collection and acclimation period on grazing rates of limnetic zooplankton. Hydrobiologia, 137:203- 210.

Gasalla, M. A. 1995. Organizaçāo trófica da ictiofauna do Saco de Mamanguá, Parati, Estado do Rio de Janeiro. Dissertação de Mestrado. Universidade de São Paulo, Instituto Oceanográfico. 145p.

Gibson, R. N.; Yin, M. C. \& Robb, L. 1995. The behavioural basis of predator-prey size relationship between shrimp (Crangon crangon) and juvenile plaice (Pleuronectes platessa). J. mar. biol. Ass. U.K., 75:337-349.

Harper Jr, D. E. 1968. Distribution of Lucifer faxoni (Crustacea: Decapoda: Sergestidae) in neritic waters off the Texas coast, with a note on the occurrence of Lucifer typus. Contr. mar. Sci. Univ. Tex., 13:1-16.

Hopkins, T. L. 1966. The plankton of the St. Andrew Bay system, Florida. Publs Inst. Mar. Sci. Univ. Tex., 11:12-64.

Hopkins, T. L.; Lancraft, T. M.; Torres, J. J. \& Donnelly, J. 1993. Community structure and trophic ecology of zooplankton in the Scotia Sea marginal ice zone in winter (1988). Deep-Sea Res., 40:81-105.

Jimenez-Alvarez, M. P. 1976. Distribuição vertical e estágios de desenvolvimento de Lucifer faxoni Borradaile (Crustacea) ao largo de Santos. Dissertação de Mestrado. Universidade de São Paulo, Instituto de Biociências. 54p.
Lampitt, R. S. \& Gamble, J. C. 1982. Diet and respiration of the small planktonic marine copepod Oithona nana. Mar. Biol., 66:185- 190.

Landry, M. R. 1978. Predatory feeding behavior of a marine copepod, Labidocera trispinosa. Limnol. Oceanogr., 23:1103-1113.

Lee, W. Y.; Omori, M. \& Peck, R. W. 1992. Growth, reproduction and feeding behavior of the planktonic shrimp, Lucifer faxoni Borradaile, off Texas coast. J. Plankt. Res., 14:61-69.

López, M. T. 1966. Biología de Lucifer faxoni Borradaile, 1915, en Cananéia, Brasil (Crustacea, Decapoda, Luciferidae). Bolm Inst. oceanogr., S Paulo, 15:47-54.

Ohman, M.D. 1988. Behavioral responses of zooplankton to predation. Bull. mar. Sci., 43:530-550.

Omori, M. 1977. Distribution of warm water epiplanktonic shrimps of the genera Lucifer and Acetes (Macrura, Penaeidea, Sergestidae). In: PROC. SYMP. WARM WATER ZOOPLANCKTON. Unesco/NIO, 1977. p. 1-12.

Oresland, V. \& Ward, T. 1993. Summer and Winter diet of four carnivorous copepod species around South Georgia. Mar. Ecol.-Prog. Ser., 98:73-78.

Parsons, T. R.; Lebrasseur, R.J.; Fulton, J. D. \& Kennedy, O.D. 1969. Production studies in the strait of Georgia. Part II. Secondary production under the Fraser River plume, February to May, 1967. J. expl mar. Biol. Ecol., 3:39-50.

Reeve, M. R.; Syms, M. A. \& Kremer, P. 1989. Growth dynamics of a ctenophore (Mnemiopsis) in relation to variable food supply. I. Carbon biomass, feeding, egg production, growth and assimilation efficiency. J. Plankt. Res., 11:535-552.

Sokal, R. R. \& Rohlf, F. J. 1981. Biometry. San Francisco, W. H. Freeman \& Co. 859 p.

Valiela, I. 1984. Marine Ecological Process. New York, Springer-Verlag. $546 \mathrm{p}$.

Vega-Pérez, L. A. 1993. Estudo do zooplâncton da região de Ubatuba, Estado de São Paulo. Publção esp. Inst. oceanogr., S Paulo, 10:65-84. 
Vega-Pérez, L. A. 1996. Estudo do zooplâncton da plataforma interna da região de São Scbastião. In: Oceanografia da Plataforma Interna da Rcgiāo de São Sebastiāo. Rclatório FAPESP n 3. 664p.

Wakabara, Y.; Flynn, M. N. \& Tararam, A. S. 1996. Consumption and selection of superbenthic crustaceans by small-sized fishes in a lower salt marsh system. Rev. bras. oceanogr. (Submitted).

Wassenberg, T. J. \& Hill, B. J. 1993, Diet and feeding behavior of juvenile and adult banana prawns Penaeus merguiensis in the Gulf of Carpentaria, Australia. Mar. Ecol.-Prog. Ser., 94:287-295.

Woodmansee, R. A. 1966a. Daily vertical migration of Lucifer (Decapoda, Sergestidae). Egg development, oviposition and hatching. Int. Revue ges. Hydrobiol., 51:689-698.
Woodmansee,R.A. 1966b. Daily vertical migration of Lucifer planktonic numbers in relation to solar and tidal cycles. Ecology, 47(5):847-850.

Yen, J. 1983. Effects of prey concentration, prey size, predator life stage, predator starvation, and season on predation rates of the carnivorous copepod Euchaeta elongata. Mar. Biol., 75:69-77.

(Manuscript received 17 August 1995; revised 19 January 1996; accepted 14 June 1996) 